\title{
MIGRATION AND SOCIOCONOMIC EFFECTIVENESS OF RUSSIA'S NORTHERN REGIONS
}

\author{
Vera P. Samarina \\ Staryy Oskol Technological Institute, Staryy Oskol, Russia \\ Tatiana P. Skufina \\ Institute of Economic Problems of the Kola Science Centre of the Russian Academy of Sciences, \\ Apatity, Russia. \\ Aleksandr V. Samarin \\ Belgorod State National Research University, Belgorod, Russia
}

Features of population settlement on the North of Russia are highlighted in this article. The determining role of the North for Russia's national economy is explained, however, it is also

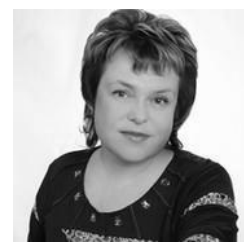

\section{Samarina Vera}

Doctor of Economic Sciences (since 2010), Professor in Economy and Head of Management Department at Staryy Oskol Technological Institute of the Research Technical University MISIS. The author of 7 textbooks and manuals for universities The founder and head of business school, based in Staryy Oskol. The expert in the Institute for Sustainable Development of the Russian Federation Public Chamber. The member of editorial boards in three federal journals in Russia and Thailand. Research interests include: planning and forecasting, social and economic development, nature management economy, regional economy, entrepreneurship, business processes. Since 2000 this coauthor has published more than 200 articles in Russian federal and international journals, including 11 journals indexed by Scopus and/or Web of Science.

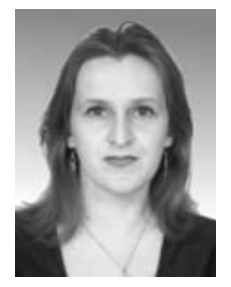

\section{Skufina Tatiana}

Doctor of Economic Sciences (since 2007), Professor (since 2013), Director of the Luzin Institute of Economic Studies of the Kola Science Centre, Russian Academy of Sciences. Research interests: public administration, regional economy, economic and mathematical modelling. The author of more than 250 articles in Russian federal and international journals, 25 monographs, 3 textbooks for universities. Expert of the Russian Academy of Sciences, expert of the Russian Science Foundation, member of the Economic Council under the Governor of the Murmansk region, member of the Public Council under the Ministry of Economic Development of the Murmansk region.

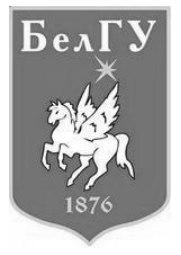

\section{Samarin Alexander}

Candidate of Philological Sciences (since 2007), Associate Professor of the Philology Department in Belgorod State Research University (Staryy Oskol branch); the author of 11 tutorials. Research interests: sociolinguistics, ethnolinguistics and cognitive linguistics. Published over 50 articles in Russian federal and international journals including 2 Scopus indexed articles; participated in 45 international conferences. 
accompanied by the growth of various socioeconomic problems in the recent years, including those directly related to depopulation. Population settlement has been considered by the authors from two interrelated positions: as the process of settling on a certain territory in the course of migration and as the final result of this process - the resettlement in various regions and zones. The article reveals the major contradictions in the development of Russia's northern territories at the present stage of their socioeconomic development. On the basis of the authors' own methodology the demographic indicators of Russia's Northern territories were compared with the average Russian ones. Then, it has been estimated how peculiar is the management of the Northern territories in comparison with other Russia's regions. According to the results of our research, directions in the migration and population settlement management have been proposed. Taking these directions into account will contribute to ensuring the socioeconomic efficiency of Russia's Northern regions.

Keywords: migration; population settlement; the Arctic zone; the Russia's North; demographic indicators; population density; migration balance; population dynamics.

\section{Introduction}

Topicality of this research has been determined due to the following contradiction: we can observe the strengthening of geopolitical and economic importance of the northern regions of the Russian Federation but simultaneously we also observe the aggravation of social and economic losses on these territories followed by urbanization and migration among northern population.

There is also an objective contradiction between the effect of the so-called "northern rise in price" in economy and social sphere functioning and the need for economic security maintenance (which includes budget replenishment) and social development of Russia's northern regions.

Most of qualitative transformations in social and economic development of the Russian North took place during the times of the Soviet Union. Closed nature of the USSR economy allowed the authorities concentrate all kinds of huge resources for the solution of strategic tasks. Centralized public management of Soviet economy also solved the problem of the rising fixed costs. At the same time, all positive effects from the North territories' development (geopolitical, economic, industrial, technological, social) also belonged only to the state. All of the above had its strong influence on the local population.

Intensive industrial development of the northern territories led to rapid growth of cities. Active migration was observed from central and southern Russia's regions to the northern areas. People were attracted by much higher salaries, opportunities to get apartments quickly and free of charge, to buy cars, furniture, household appliances and to provide themselves with some other material benefits, inaccessible and not affordable to the rest of the Soviet Union.

Even today the authorities continue to work under this effect of "northern prices", and this is applicable to both the economy and the social sphere. However, there is hardly any opportunity to accompany the rising prices with positive effects for the local development. This objective divergence is limiting the development opportunities in both social and economic sectors of the Russian North, while administrative impacts only strengthen this divergence. Today, under the conditions of market economy the state cannot guarantee high wages for everyone in the region. Moreover, people do not have the opportunity to get apartments quickly and free of charge anymore. Cars, furniture, household appliances etc. are not deficit anymore. Provided there is high enough salary, people living in other regions of 
the Russian Federation can easily buy all of the above, residing in climatically comfortable conditions at the same time. This contradiction determines relatively new directions in the migration processes inside Russia.

There is also another contradiction, of purely administrative nature. This contradiction is related to the conflict between the declared orientation on the innovative sectors and the objective reality of Russia's economy functioning. The reality is that in the foreseeable future mining and mineral resource will still determine Russia's key competitive advantages in the context of global economy. Thus, all related sectors will still be serving as budget donors, and also as the basis for modernization of all other sectors and development of high technologies. Therefore, mining and mineral resources will also predetermine, to a large extent, the directions in the processes of urbanization and migration. This means that population residing on the northern territories of Russia will be also subject to all these influences.

On the other hand, foreign experience in northern regions' management certainly should be considered in the course of balancing economic efficiency and social comfort criteria. However, considering the level of problems on Russia's northern territories, their scale, complexity and importance for national economy, there are actually no analogues in foreign countries which also have northern territories. Figuratively speaking, an attempt to consider foreign experience in the northern areas' management as the solution for development of Russia's northern territories is similar to constructing a car after studying the examples of bicycles.

Generally speaking, the common theory of the North territories' development is still very much inconclusive. For example, till now there is no theory capable of offering an effective mechanism for social relations in the course of Russia's northern zones' development. In this regard an important task would be to develop a dynamic system for population placement on the Russian North.

The statement of this task assumes a cross-disciplinary approach and complexity of the research by default. The innovative character of such research is predetermined by the current management demanding the development of the objective scientific theory of social and economic development for the North of Russia. The authors of this article are the members of several expert commissions and economic councils such as the Council for Improvement of Investment climate in Murmansk region. Thus, we can reasonably claim that there is indeed a demand on the side of local management for such a theory. And this demand assumes, inter alia, formulation of an absolutely new approach to Russia's northern territories management.

The Arctic zone of the Russian Federation is a separately subject among all northern areas which are treated as a unified macroobject here. The macroobject is the system of zones in each Arctic region. That is, for the first time in the world practice of the Arctic territories management, development of the Russian Arctic territories will represent the unified project of planning through interconnection of all federal, regional and branch measures of social and economic character at the points of planning, goal-setting, financing and implementation. We should also note here that the important place at the same time has to be allocated to funding and other forms of support for the projects increasing natural growth of population and also immigration into the Arctic areas. At the same time such funding has to take into account changed demand and new requirements to labor power on the northern territories, including the Arctic zone. 


\section{MIGRATION AND SOCIAL - ECONOMIC}

Therefore, the fundamental goal of this research is to solve the following problem: to analyze the current and forecast the future trends in population distribution on the North of Russia and then to find out to what extent Russia's northern regions have acquired and kept up the features of typical frontier territories. Such a problem statement predetermines in advance the cross-disciplinary approach and the complexity of this research.

To achieve the research goal it is necessary to solve the following problems:

- to investigate and characterize the distribution of population on the Northern Territories of Russia on the basis of complex indicators;

- to identify the directions and the nature of population migration on the Russian North in different time periods;

- to ground the belonging of Russia's northern regions to the frontier ones on the basis of the authors' own methodology;

- to assess the management features for all these territories belonging to the Russian North in comparison with other territories of the Russian Federation.

In our study we proceed from the following hypotheses:

- firstly, Russia's northern regions are poorly populated and continue to lose their population;

- secondly, migration in the regions of the North is voluntary; it has an economic character mostly and its direction has been changing depending on economic and social conditions;

- thirdly, Russia's northern regions have lost the features of frontier territories recently;

- fourthly, Russian authorities do not contribute to the development of the northern territories as frontier ones due to widespread centralization of management;

- fifthly, solving the problems of the North settlement is the key to solving the problems of Russia's development overall.

\section{Literature review}

The problematics of social and economic development of the North includes the wide range of economic, social, legal, natural and scientific problems considered in various aspects and on various reasons. At the same time in managerial economics of the northern territories, as well as in general in economic science, there are no rules to determine the "correct" direction in the development, as opposed to the "wrong" one. The situation becomes worse because at present most of the research studies concerning management problems of the North dates back to the times of the USSR, while foreign experience is simply not applicable to the solution of the most difficult management problems in the development of Russia's northern zones, including urbanization and migration problems.

Political and economic problems arising in the course of social and economic development of the northern territories have been analyzed in a large number of research papers covering various aspects of socioeconomic life on the North (Adamesku et al., 2003; Kondrashev et al., 2016). There is a number of general conceptual ideas that can be to some extent useful for us, offered by the scientists from foreign countries having northern territories (Denmark, the USA, Canada, Norway, Iceland, Sweden, Finland).

First and maybe most serious one is the problem with necessity of preserving quantitative and qualitative demographic potential of the northern zone. Secondly, there is a problem with protectionism and compensation in both economic and social spheres. Third 
comes the priorities of "non-destructive" social and economic development. These theses are reflected, inter alia, in the works by R. Andrew (Andrew, 2014), H. Bjornland and L. Thorsrud (Bjornland \& Thorsrud, 2014), D. Brigt, I. B. Larsen and B. Skorstad (Brigt, Larsen \& Skorstad, 2017), G. Sabathil (Sabathil, 2010), A. Gill and D. Sevigny (Gill \& Sevigny, 2015), D. Ushakov, I. Elokhova and E. Kozonogova (Ushakov, Elokhova \& Kozonogova, 2017).

A special place takes the number of works reflecting the problems with North settlements in inaccessible and underdeveloped territories. Such settlements have their own features. On the one hand, traditional features of housekeeping of the native northern population are based on nomadic deer-raising, hunting and fishery. Such traditions mean quite rational nature management which does not break the natural balance (Hamilton, Saito, Loring, Lammers \& Huntington, 2016). Similar conclusions were also drawn by (Heleniak \& Bogoyavlensky, 2015; E. Niels, J. N. Larsen and A. Nilsson, 2004).

On the other hand, native northern people's main problems lie in traditional housekeeping. Their work is hard and low-paid, and they live without any benefits of civilization. Native northern people's lifetime is not that long; traditional lifestyle accompanied with alcoholism exert negative influence on it. Alcohol exerts especially damaging influence on northern people's organisms due to their inherited physiological features. This sort of problems is killing nearly all northern people, not only those living in Russia. Many foreign scientists also mention it, including E. S. Gomberg (Gomberg, 2003); D. Fenna., L. Mix, O. Schaefer and J. A. Gilbert (Fenna, Mix, Schaefer \& Gilbert, 2017); D. S. Wood (Wood, 1999). Among Russian researchers sharing their opinions on this problem we can mention A. I. Kozlov and E. V. Zdor (Kozlov \& Zdor, 2003), and also N. P. Koptseva (Koptseva, 2013).

It is necessary to pay attention to another important issue. As a rule, children born on the Russian North go and live in boarding schools in larger cities where they are given compulsory secondary education or vocational technical training. Native northern people in Russia have some preferences while entering universities. As a result, northern people's children acquire professions but then do not come back to the settlements where they were born. Having experienced vast opportunities and various temptations of civilization, young people do not want to come back to complicated and poorly-paid way of life of their parents and grandparents. K. Graves (Graves, 2005); R. J Shephard and A. Rode (Shephard \& Rode, 1996); L. Suopajärvi, T. Ejdemo, E. Klyuchnikova, E. Korchak, V. Nygaard and G. A. Poelzer (Suopajärvi, Ejdemo, Klyuchnikova, Korchak, Nygaard \& Poelzer, 2017) all pointed out to this problem in their research studies.

On the other hand, in some northern territories rich deposits of oil, gas, gold and other minerals have been found (Burn, Magdanz, Stotts, Berman \& Kofinas, 2016; Hausmann \& Rodrik, 2016; Sachs \& Warner, 2001). Development of such fields on the North very seldom meets the current requirements of nature management and "green economy". I. A. Ignatyeva (Ignatyeva, 2003); M. K. Peshkova and D. Y. Savon (Peshkova \& Savon, 2016); D. Rodrik (Rodrik, 2013) have described the accompanying problems in more detail. The concept of the population settlement near the places of mining operations is in fact the direct opposite to the concept of native northern people's living (Jorgensen, 1990; Overpeck, Sturm \& Francis, 2005). When it comes to fields' development, people's life nearby is always temporary, and they know it. Thus, there is no sense of growing attachment to this territory. Most of such deposits in Russia are developed under the "rotational" method, workers are recruited for 


\section{MIGRATION AND SOCIAL - ECONOMIC}

short periods of time. Groups of workers carry out certain works within two months (as a rule) and then leave, sometimes for good, sometimes they return for another shift, later. Another group of workers comes to change them. These "rotational" settlements have no time, neither motivation to develop social and cultural infrastructure, they provide only very basic accommodation (Anas \& Xiong, 2005; Kozlova \& Ushakov, 2016). Such settlements are common not only in Russia, but also in some other countries, and not only on northern territories, but also on other poorly populated lands which are difficult to access but which are still an interesting area for businesses and state authorities, mostly due to availability of certain resources (Animica \& Novikova, 2009; Caravelis \& Russell, 2003; Morgan, 2004; Otto \& Fornahl, 2007; Todtling \& Trippl, 2004).

Taking into account relative stability of these conceptual theses of the development and the lack of serious contradictions among policy and management, most of contemporary foreign studies on social and economic development of the North are directed on finding the applied solutions for these problems. Analyses of the related problems carried out by intergovernmental Arctic organizations and research institutes from different countries point out to their closeness implicitly. Among these problems are: welfare problems of the people living on the northern territories; development of education on these area; ensuring equality in access to goods and services; development of infrastructure for life quality improvement; native northern peoples' adaptation to social and economic life and also to contemporary legal requirements (Agrawal, Cockburn \& Rosell, 2004; Black, Adger, Arnell, Dercon, Geddes \& Thomas, 2011; Howe, Huskey \& Berman, 2014; Spence, 2014; Torre \& Wallet, 2014). The last problem arises from the fact that there is a discrepancy between native peoples' interests on the one hand and economic, social, ethical requirements of contemporary societies on the other.

Contemporary Russian research studies on the problems of the northern population differs from the international ones. This can be explained with the following objective and subjective factors. Most of the objective factors are related to special status and significance of the Russian northern territories for the national economy. Such territories in developed countries of the world are mostly subsidized, whereas in Russia these lands are the key to future national income (for example, 93\% of all gas are extracted from the northern territories). Another objective factor is that the level of social and economic development of the North in the period of the USSR exceeded the development levels observed in other foreign countries also having northern territories. However, nowadays the northern territories abroad, especially in terms of social sector development, have significantly outstripped the development of the Russian North. In the Russian Federation infrastructure of the Soviet period is still in use in many localities, and this leads to quite predictable reduction of many social and economic indicators (Samarina, Skufina \& Samarin, 2016; Silin, 2015; Skufina, Baranov, Samarina \& Shatalova, 2015; Samarina, Skufina, Samarin \& Ushakov, 2018).

The third objective factor is that most of foreign countries, also having northern territories, today have sufficient resources for further systematic development of their Arctic territories, meanwhile the Russian Federation, in case of ongoing losses of infrastructure and in human capital, will have no resources for the renovation of the North.

Subjective factors are determined by one central reason. In contrast to developed countries, all issues related to population residing on Russia's northern territories is not considered to be of top priority for the national territorial policy. This lack of attention becomes a real threat to national security, as it has been already mentioned in several 
research papers on this research topic. A number of researchers have already tried to place more emphasis on theoretic and methodological bases of the North development. They have clearly demonstrated the insufficiency of today's policies and offered their own versions of sustainable development plans for the northern territories (Pilyasov, 2017; Silin, 2015; Skufina, Samarina, Krachunov \& Savon, 2015).

There is a point of view that northern territories can be referred to as frontier ones. A number of researchers adhere to this position, including M. Fujita and T. Mori (Fujita \& Mori, 2009), J. B. Waldram, D. A. Herring and T. K. Young (Waldram, Herring \& Young, 1995), and also N. Y. Zamyatina (Zamyatina, 1998). Frontier territories radically differ from outlying lands. The former have their own, special mechanisms of development, prevalence of innovative projects in entrepreneurship, passional personal significant impacts on their development (Billington, 1991; Saxenian, 2006). Another distinctive features of frontier territories is that they have specific demographic characteristics (Arctic Human, 2018; Berman, 2013).

During the times of communist rule, population residing within Russia's northern territories was mainly considered from the positions of providing these lands with manpower resources (Adamesku, Granberg \& Kistanov, 2003).

At present time the starting point in many related researches concerns the determination of the influences of economic, social and other factors on the population of the northern areas. This clearly demonstrates there is a practical necessity for consideration of the problems related to population living on these lands.

\section{Indicators of population settling in the Russian Federation regions located on the North}

First of all, let us consider the statistical indicators of the population settling in the Russian Federation subjects whose territories are completely or partially located on the North. The presented data belongs to the Federal State Statistics Service of the Russian Federation as of 2018 (Federal State..., 2018). We have extracted the data of interest for us into Table 1.

The total territory of the Russian Federation is 17,125,191 square km (Federal State..., 2018). At the same time, the total area of what is called the Russian North, is 782,292 square $\mathrm{km}$, or $45.66 \%$ of the country's territory. The total area of the Russian Federation subjects, partially located in the North zone is 8989150 square km, or $52.49 \%$ of the country's territory. Thus, the area of the Russian Federation subjects, completely or partially referred to as the North, is actually $98.16 \%$ of the country's territory. The zone of the North itself occupies more than $70 \%$ of the Russian territory. No other country on the planet Earth has such vast northern territories!

At the same time, the share of the urban population residing on the northern territories is quite high. The increased share of urban population has been caused by the intensely industrial character of the North territories' development. Urban population in the Russian Federation is $74.43 \%$, as of 2018. But on the northern territories it is slightly higher, on average, about $78.66 \%$. The highest indices of industrial/urban development have the following regions: Magadan Region (95.89\% of population residing in cities and towns), Khanty-Mansi Autonomous Area (92.34\%) and Murmansk Region (92.33\%). The only 
exceptions are the Republic of Tuva (54.04\% of people residing in cities) and the Republic of Sakha (Yakutia) (64.01\%).

Table 1. Some statistical indicators of the Russian Federation subjects, located in the Northern zone, as of 2018

(Source: Federal State Statistics Service of the Russian Federation, 2018)

\begin{tabular}{|c|c|c|c|c|c|c|}
\hline & $\begin{array}{l}\text { Subjects of the Russian } \\
\text { Federation }\end{array}$ & 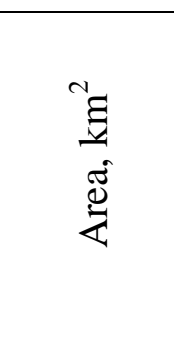 & 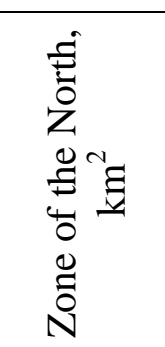 & 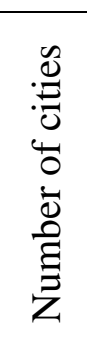 & 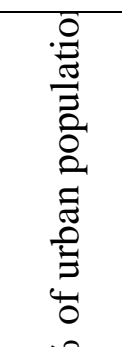 & 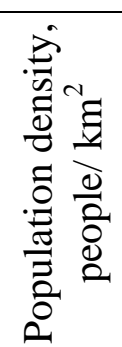 \\
\hline \multicolumn{7}{|c|}{ Subjects of the Russian Federation fully located in the North zone } \\
\hline 1 & Murmansk region & 144900 & 144900 & 16 & 92,33 & 5,20 \\
\hline 2 & The Republic of Karelia & 180520 & 172400 & 16 & 80,41 & 3,45 \\
\hline 3 & Arkhangelsk Region & 589913 & 234000 & 32 & 78,00 & 1,96 \\
\hline 4 & Nenets Autonomous Okrug & 176810 & 176810 & 1 & 72,84 & 0,25 \\
\hline 5 & The Sakha Republic (Yakutia) & 3103200 & 3103200 & 13 & 64,1 & 0,31 \\
\hline 6 & Chukotka Autonomous District & 721481 & 721481 & 3 & 70,51 & 0,07 \\
\hline 7 & Kamchatka Territory & 464275 & 464275 & 3 & 78,22 & 0,68 \\
\hline 8 & Sakhalin Oblast & 87101 & 87101 & 14 & 82,02 & 5,63 \\
\hline 9 & Magadan Region & 462464 & 462464 & 2 & 95,89 & 0,31 \\
\hline 10 & Yamal-Nenets Autonomous Area & 769250 & 769250 & 8 & 83,82 & 0,70 \\
\hline 11 & Khanty-Mansi Autonomous Area & 534800 & 534800 & 16 & 92,34 & 3,09 \\
\hline 12 & The Republic of Tuva & 168604 & 168604 & 5 & 54,04 & 1,91 \\
\hline 13 & The Republic of Komi & 416774 & 416774 & 10 & 78,11 & 2,02 \\
\hline \multicolumn{7}{|c|}{ Subjects of the Russian Federation partially located in the North zone } \\
\hline 14 & Tomsk Oblast & 314391 & 259040 & 6 & 72,41 & 3,43 \\
\hline 15 & Khabarovsk Territory & 787633 & 654000 & 7 & 82,13 & 1,69 \\
\hline 16 & Tyumen Region & 1464173 & 47850 & 5 & 80,66 & 2,52 \\
\hline 17 & Krasnoyarsk Territory & 2366797 & 463261 & 23 & 77,39 & 1,22 \\
\hline 18 & Irkutsk Region & 744846 & 475170 & 22 & 78,78 & 3,10 \\
\hline 19 & Primorsky Krai & 1913037 & 38450 & 12 & 76,32 & 11,62 \\
\hline 20 & The Republic of Altai & 92903 & 38407 & 1 & 28,65 & 2,35 \\
\hline 21 & The Republic of Buryatia & 351334 & 186800 & 6 & 59,01 & 2,80 \\
\hline 22 & Zabaikalsky Territory & 431892 & 152110 & 10 & 68,22 & 2,48 \\
\hline 23 & Amur Region & 361908 & 219370 & 10 & 67,37 & 2,21 \\
\hline 24 & Perm Krai & 160236 & 32770 & 25 & 75,80 & 16,3 \\
\hline
\end{tabular}

Among the regions partially located in the North zone, the share of urban residents is lower as compared to the same share in the regions located fully within the Russian North. The average value for both is $69.70 \%$. This is lower than the average share of urbanized population for the Russian Federation overall. The highest rate belongs to Khabarovsk 
Territory (82.13\% of all local citizens). The lowest indicator belongs to the Republic of Altai which has only one large city and the share of urban population is thus only $28.65 \%$.

\section{Key features of settlements in the Northern regions}

The overall number of cities on the northern territories is small. As it can be seen in Table 1, at present there are 139 urban settlements being fully located within the boundaries of the Russian North. There are also 127 urban settlements partially located on the North. There are also regions with only one urban settlement as such. For example, Nenets Autonomous Okrug, is fully located on the northern territories with the total area of 177 thousand $\mathrm{km} 2$, or the Altai Republic, partially Northern territory, with the area of 93 thousand $\mathrm{km} 2$. Two cities are located in the Magadan Region, the territory of which covers 462 thousand $\mathrm{km} 2$. The Chukotka Autonomous Okrug (721 thousand $\mathrm{km} 2$ ) and Kamchatka Territory (464 thousand $\mathrm{km} 2$ ) both have only three cities despite the fact that their territories are really huge. At present, $79 \%$ of all northern cities are small, they are home to $40 \%$ of all Russian northerners.

The key feature of the majority of rural settlements on the northern territories is their non-agricultural orientation. Most often these are industrial settlements - builders, miners and drilling workers are residing there. In addition, there are also settlements that arose in course of the military-industrial complex development: military "towns", frontier posts, armed forces servicemen settlements etc. Another peculiarity of the population resettlement in the North is the existence of a highly specific group - closed settlements. They are associated, as a rule, with nuclear weapons production, large military bases and weapon testing etc. In Murmansk region there are 5 such settlements, 1 - in Arkhangelsk region, 1 in Tomsk Oblast, 1 - in Amur Region, 5 - in Krasnoyarsk Territory, 2 - in Kamchatka Territory, 2 - in Zabaikalsky Territory and 3 - in Primorsky Krai.

The monofunctionality of small towns and settlements of the North determines high unemployment rate in them. Population's purchasing power is low, the majority of the inhabitants in such settlements do not have any opportunity to move to more favorable areas for life, that is, to the central and southern regions of Russia. In addition, the northern regions are located above the isoline of sustainable crop cultivation, that is, they are unsuitable for farming. Self-employment in farming is often the only opportunity for survival for the unemployed population in other regions of the Russian Federation, however, in the case of the northern territories farming is not an option at all. As a result, migration occurs mostly in the direction to large northern cities, therefore, population the latter is growing all the time.

One of the most negative features of the northern regions is their low level of diversification. Many northern municipalities are the so-called monotowns. There, people who have been dismissed from an enterprise often do not have a chance to find employment somewhere else. This problem of systemic unemployment inevitably leads to stagnation of business and economic activity in the whole region overall. Moreover, total dependence from the tax revenues of the single enterprise is not financially healthy for any region, no matter where it is situated. The multiplicative effect here is that these monotown's problems are leading to problems' accumulation in the region as a whole (Bartik, 2009; Rodrik, 2008; Tötzer, Gigler, 2005; Trippl, Otto, 2009). Thus, there is a significant decrease in population standards of living and escalation of social instability regionally. 


\section{Population dynamics on Russia's northern territories and the migration balance}

Let us consider the population dynamics on Russia's northern territories during the period from 1958 to 2018 . The data is presented in Table 2.

Table 2. Dynamics of population on Russia's northern territories

(Source: Federal State Statistics Service of the Russian Federation, 2018)

\begin{tabular}{|c|c|c|c|c|c|c|c|}
\hline \multirow[b]{2}{*}{ Subjects of the Russian Federation } & \multicolumn{6}{|c|}{ Population, thousand people } & \multirow{2}{*}{ 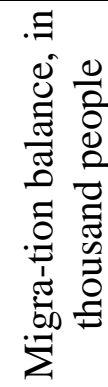 } \\
\hline & 1929 & 1959 & 1979 & 1989 & 2009 & 2018 & \\
\hline \multicolumn{8}{|c|}{ Subjects of the Russian Federation completely located on the North } \\
\hline \begin{tabular}{|l|l|} 
Murmansk region & \\
\end{tabular} & 24 & 568 & 965 & 1147 & 886 & 754 & $-3,5$ \\
\hline The Republic of Karelia & 247 & 651 & 736 & 791 & 690 & 622 & $+0,1$ \\
\hline Arkhangelsk Region & 432 & 1230 & 1420 & 1555 & 1272 & 1155 & $-5,2$ \\
\hline Nenets Autonomous District & 15 & 37 & 47 & 55 & 42 & 44 & $+0,1$ \\
\hline The Sakha Republic (Yakutia) & 280 & 487 & 820 & 1072 & 951 & 964 & $+2,2$ \\
\hline Chukotka Autonomous District & 14 & 47 & 133 & 157 & 51 & 49 & $-0,2$ \\
\hline Kamchatka Territory & 28 & 221 & 378 & 466 & 334 & 316 & $-2,7$ \\
\hline Sakhalin Oblast & 17 & 648 & 655 & 710 & 519 & 419 & $-4,0$ \\
\hline Magadan Region & 20 & 189 & 333 & 386 & 183 & 144 & $-3,2$ \\
\hline Yamal-Nenets Autonomous Area & 32 & 62 & 158 & 482 & 543 & 539 & $+0,4$ \\
\hline Khanty-Mansi Autonomous Area & 23 & 123 & 569 & 1268 & 1433 & 1655 & $+8,9$ \\
\hline The Republic of Tuva & $\mathrm{n} / \mathrm{a}$ & 172 & 267 & 309 & 306 & 322 & $-0,7$ \\
\hline The Republic of Komi & $\mathrm{n} / \mathrm{a}$ & 815 & 1119 & 1261 & 1006 & 841 & $-6,0$ \\
\hline \multicolumn{8}{|c|}{\begin{tabular}{|c|} 
Subjects of the Russian Federation partially located on the North \\
\end{tabular}} \\
\hline Tomsk Oblast & $n / a$ & 747 & 866 & 1001 & 1039 & 1078 & $+0,8$ \\
\hline Khabarovsk Territory & 187 & 979 & 1376 & 1609 & 1437 & 1329 & $+0,7$ \\
\hline Tyumen Region & $\mathrm{n} / \mathrm{a}$ & 1092 & 1887 & 3080 & 3400 & 3692 & $+10,5$ \\
\hline Krasnoyarsk Territory & $\mathrm{n} / \mathrm{a}$ & 2160 & 2637 & 2948 & 2908 & 2876 & $+3,2$ \\
\hline Irkutsk Region & $\mathrm{n} / \mathrm{a}$ & 1977 & 2559 & 2831 & 2446 & 2404 & $-5,0$ \\
\hline Primorsky Krai & 724 & 1381 & 1978 & 2258 & 2071 & 1933 & $-5,5$ \\
\hline The Republic of Altai & 101 & 157 & 172 & 192 & 203 & 218 & $+0,1$ \\
\hline The Republic of Buryatia & 391 & 673 & 900 & 1041 & 981 & 984 & $+1,5$ \\
\hline Zabaikalsky Territory & $n / a$ & 990 & 1165 & 1301 & 1083 & 1073 & $-0,2$ \\
\hline Amur Region & 509 & 718 & 937 & 1058 & 895 & 798 & $-2,8$ \\
\hline Perm Krai & 2321 & 2992 & 3009 & 3095 & 2718 & 2623 & $+0,1$ \\
\hline
\end{tabular}


As we can see, resettlement of population residing on the Russian North has been increasing since the 1930s. The causes of migration were mainly related to industries' development. At the same time, people were either relocated by force in the course of mass deportations (forced migration) or were attracted by various benefits (raised wages, lowered retirement age, no problems with accommodation, all family members' free of charge twoway travel during the holidays etc.). Thus, the second one was voluntary migration.

Mass forced migration practically stopped during the 1960s. Voluntary migration greatly exceeded the forced one in volume. The population of the northern regions was constantly growing. Table 2 shows that the largest population volume in all the regions in question was observed in 1989. The population boom continued until the early 1990s, till the very collapse of the Soviet Union.

After the Soviet Union collapse, the population began to decline sharply. Under the conditions of market economy, the state cannot guarantee the previous "northern privileges" and higher salaries in particular. Many enterprises of the North got closed, unable to withstand competition with foreign and Russian enterprises that had much lower costs. High costs on the northern enterprises are associated not only with climatic and geographical features, but with the need to pay higher wages to all employees. As a result, having lost highly paid jobs and all the accompanying benefits, the people began to move massively to other Russia's regions in search for more comfortable conditions and alternative job opportunities. Table 2 also shows that over the 20 years, from 1989 to 2009, the population in all the northern regions significantly decreased. The reasons for migration were nearly always economic ones, and that was voluntary migration only, of course.

This situation remained unchanged until recently. In recent years, the population has begun to return to some of the northern territories. Thus, in 2018, as compared with 2009, the population of the Nenets Autonomous District, the Republic of Sakha (Yakutia), and Khanty-Mansiysk Autonomous Okrug has increased. The balance of migration in these regions became again positive in 2018 . We need to mention here that all these regions are oil producing. Thus, the population is attracted by high wages paid by oil-producing enterprises. Today, positive balance of migration and its voluntary nature, due to economic and welfare reasons, makes it possible to classify the allocated regions as frontier ones. The situation is not so good in the remaining northern regions though, since the balance of migration on all other areas of the Russian North is still negative.

The situation in the regions partially located on the North is ambiguous as well. In 2018 as compared to 2009 the population of oil-producing Tomsk and Tyumen regions has increased. The balance of migration in these regions is positive, as of 2018. The population of the Republic of Altai and the Republic of Buryatia has also increased. These regions are rich in minerals but they have no oil, they are subsidized and traditionally underdeveloped socio-economically. In other regions the population numbers have not reached the 2009 level yet. But as of 2018 the balance of migration in most of these regions is already positive and this indicates that the population is returning to the northern territories. The reason for such migration trends is the same - the economic one. And again, it is voluntary migration.

As of 2018, the population of the Russian Federation is 146.8 million people (Federal State..., 2018). In the northern territories reside 7824 thousand people, or 5.33\% of Russia's total population. There are also 19,008 thousand people, or $12.94 \%$ of Russia's entire population, residing on the territories partially located on the North. Altogether, 26832 thousand people, or $18.27 \%$ of Russia's total population live on the territories completely or 


\section{MIGRATION AND SOCIAL - ECONOMIC}

partially located on the North. Comparing these values with the area of the territories of the Russian Federation, wholly or partly located in the North $(98.16 \%)$, we can see that the minimum numbers of population are living on these vast territories.

\section{Peculiarities of Russia's northern territories management}

Peculiarities of Russia's northern territories' management are determined by the causes of very different levels, and each level puts emphasis on its own geopolitical, macroeconomic, mineral and social factors.

Global level. Uneven distribution of natural resources, their gradual but inevitable depletion, less and less opportunities for discovering new deposits in favorable conditions and, at the same time, the growing needs of the world economy - all strengthens the struggle for resources. The heavy load of this reason has already caused certain territorial losses for Russia. Namely, according to the agreement as of 2010 concerning the delimitation of the "gray zone" in the Barents Sea with Norway, Russia lost some territories rich in hydrocarbon raw materials and bioresources forever. These territorial losses in the northern zone have their geopolitical and economic consequences for Russia. Most of the related economic losses are quite direct and obvious, however, indirect losses are important as well. The current state of affairs and seas' division has strengthened Norway's position in the long term. Norway today is the main competitor of Russia at European oil and gas market. At the same time, the largest Russian Stockman project was curtailed due to difficulties with gaining access to Western offshore mining technologies etc.

The social side of management also has its regional, sectoral and even global levels here.

Natural-climatic and geographical features make the North probably the least attractive option for living. Such situation is not unique to Russia only. A number of foreign researchers of the North mention this fact, for example, M. Berman and L. Howe (Berman \& Howe, 2012).

\section{Macroeconomic level.}

Changes in the protectionist policy towards the North has led to a massive loss of its socioeconomic features. They are also in contradiction with the economic requirements of these territories and the whole situation entails irreplaceable infrastructural losses and leads to a truly geopolitical sort of problem of the so-called "empty space". Tracking the objective dynamics and forecasting the migration processes' development in the Russian North is important not only for the northern zone itself but for territorial development of Russia as a whole.

Disclosing and forecasting the development dynamics of the northern zone within the framework of concretizing specific tasks of the federal government leads to formulation and application of a brand new approach to management - the spatial one. This approach is based on the idea of singling out a macroobject - Russia's northern zone. The authors of this 
article are the members of the working groups which were created to analyze numerous versions of the draft of the federal law "On the Development of the Arctic Zone of the Russian Federation" (hereinafter - the Draft Law). This document was planned as a kind of "Arctic Code", covering the management of a wide range of development problems specific for Russian northern territories. However, on January 31, 2017 yet another version of the draft was rejected and sent back for further revision, with the recommendation to focus only on the mechanism of support. At the time of this article submission the draft has been revised in accordance with the instructions. It regulates only the relations that evolve in the course of formation and functioning of the supporting zones, including the conditions for provision of direct support to the northern territories' population (On the development..., 2018).

\section{Regional level.}

Living on the North, on the one hand, implies low level of comfort and increased risks for population. On the other hand, there is a permanent need for regional authorities to ensure vital activity processes for all citizens residing on the northern territories. At the same time, the authorities should not only build and maintain northern cities' and other settlements' infrastructure. It is much more important to ensure social and economic development of the northern territories overall. Increasing the level of social and economic development is mentioned as the key goal in the State Program "Socioeconomic development of the Arctic zone of the Russian Federation", presented in a new edition in 2017 (Socioeconomic development ..., 2017).

The regions themselves are mainly responsible for achieving this Program's targets. None of the northern regions has been able so far to solve their problems on their own. Possibility of the problem solving is directly related to the investment mechanism which may generate large sectoral projects (often called "anchor projects"). Most of these anchor projects are usually associated with the mining specialization of the Russia's regions located on the North. Implementation of such projects would be regarded as a stabilizing factor ensuring long-term development of the northern regions.

From the standpoint of the northern regions themselves, ensuring socioeconomic development means finding new more opportunities how to participate in the mentioned above "anchor projects" and to develop on their basis a network of smaller ("non-anchored") projects.

The most complex government target would be to generate a sufficient number of such projects, taking into account the effectiveness of state-owned and private companies activities included in these projects, predominantly under market conditions.

\section{Conclusion}

Currently, large areas of the Russian North remain uninhabited: population density in 6 regions out of 13 , fully located on the North, is less than 1 person per $1 \mathrm{sq} . \mathrm{km}$. 


\section{MIGRATION AND SOCIAL - ECONOMIC}

Oil-producing regions are the most economically developed ones among the regions of the North. For obvious reasons, they are also most attractive for population.

The positive balance of migration and its voluntary nature, caused by purely economic reasons, makes it possible to classify the allocated regions as developing ones. The situation is not so good in the remaining northern regions, the balance of migration in most of them is negative (as of 2018). Thus, the first hypothesis, concerning the fact that Russia's northern territories are poorly populated and continue to lose their population proved to be correct for most of the regions in question.

It is obvious that population living conditions are largely influenced with the indicators of socioeconomic development. A region developed in social and economic terms is nearly always attractive for migrants. But as soon as the economic recession begins and population starts losing high wages and social preferences, population outflow from the North starts nearly immediately. Thus, the second hypothesis that migration in the North regions is voluntary, is of economic nature and its direction change depends on economic and social conditions, turns out to be correct.

We have found that according to the demographic indicators a fair number of the northern regions can be referred to frontier territories. According to the gender ratio, there is an excessive number of men over the number of women; the average age of local population is lower in comparison with other territories (in other words, population on the Russian North is generally slightly younger than in Russia on average); the natural increase coefficient is positive; the balance of migration is positive as well; according to classification of reasons/motivations, the migration is economic and voluntary one. At the same time, management of the northern areas remains to be very much centralized. Therefore, from the viewpoint of management features, Russia's northern territories cannot be considered frontier ones. Thus, our third hypothesis that Russian northern regions have lost the features of frontier territories, has been confirmed partially.

It is the federal center that is trying to adapt the northern regions to the standards of frontier territories in terms of management features. The authorities try to develop special development mechanisms, increase the share of innovative projects, in the sector of entrepreneurship especially, and attract more passionate individuals who can really influence the development of these territories. Our fourth hypothesis concerning the fact that Russian authorities do not contribute to the development of the northern territories as frontier ones due to widespread centralization of management has not been confirmed.

In conclusion, it is necessary to note that the importance of the northern territories will only grow, at least in the near future. For example, the consulting company Rustad Energy determines that by 2020 the territories of the North will cover around $3 \%$ of the world hydrocarbon production, and by 2035 its share will, most probably, grow to the level of about 9\%. Thus, development of the northern territories' wealth is actually a global trend for the foreseeable future. Thus, for Russia, development of the northern territories should be a dayto-day strategic task, especially in what concerns land deposits and offshore projects. These 
territories on the North will continue to be the resource base of Russian economy as a whole, and this fact confirms the fifth hypothesis that the solution of the problems of the northern territories is the key to solving the problems of Russia's development in general.

Further migration of population from the northern territories not only undermines the economic potential of Russia, but also creates additional problems with geopolitical security. We have to note here that in other countries with near-polar territories, the state seeks to increase the inflow of people to sparsely populated northern areas due to the fact that empty areas tend to turn into the zone of potential risk. To address this problem, the territories of the North need to be developed and inhabited as well. Otherwise, Russia can lose both its labor resources in the North, and territories rich in minerals and other resources vital for its further development.

\section{Acknowledgement}

The study includes the research findings under the project of the Russian Foundation for Basic Research and the Ministry of Economic Development of the Murmansk Region No. 17-46-510636 "Unevenness of socioeconomic development of cities and regions of the European North of Russia: trends, patterns, forecast of impact of bearing zones of development of the Arctic" (results of the situation analysis) and the results obtained in the course of performing the state assignment of the Federal Research Centre of the Kola Science Centre of the Russian Academy of Sciences (in part of management issues).

\section{References:}

Agrawal, A., Cockburn, I. \& Rosell, C. (2010). Not Invented Here? Innovation in company towns. Journal of Urban Economics, 67, 78-894.

Adamesku, A.A., Granberg, A.G. \& Kistanov V.V. (2003). State and Territorial System of Russia (Economic and Legal Basics). Moscow: DeKa.

Alien, K. \& Yuill, D. (2007). European Regional Incentives. A Survey of Regional Incentives in the Countries of the European Community and Sweden. Glasgow: European Regional Policy Monitoring Unit.

Anas, A. \& Xiong, K. (2005). Formation and growth of specialized cities: efficiency without developers or Malthusian traps. Regional Science and Urban Economics, 35, 445-470.

Animica, E. G. \& Novikova, N. V. (2009). Challenges and prospects for development of singleindustry towns of Russia. Manager, 1-2, 46-54.

Andrew, R. (2014). Socio-economic drivers of change in the Arctic. AMAP technical report no. 9. Oslo: Arctic Monitoring and Assessment Program. Accessed November 11, 2014.

Arctic Human Development Report: Regional Processes and Global Linkages (2014). Ed. by J.N. Larsen, G. Fondahl. Copenhagen: Tema Nord; Norden.

Bartik, T. J. (2009). The Revitalization of Older Industrial Cities: A Review Essay of Retooling for Growth. Growth and Change, 40 (1), 1-29. 


\section{MIGRATION AND SOCIAL - ECONOMIC}

Berman, M. \& Howe, L. (2012). Remoteness, Transportation Infrastructure, and Urban-Rural Population Movements in the Arctic Proc. Int. Conf. Urbanisation of the Arctic, Nuuk, Greenland, August 2012. Stockholm: Nordregio, 108-122.

Berman, M. (2013). Modeling Regional Dynamics of Human-Rangifer Systems: A Framework for Comparative Analysis. Ecology and Society, 18(4), 43-49.

Billington, R. A. (1991). America's Frontier Heritage. Albuquerque: University of New Mexico Press.

Bjornland, H. \& Thorsrud, L. (2014). What is the effect of an oil price decrease on the Norwegian economy. Oslo: Norges Bank.

Black, R., Adger, W. N., Arnell, N. W., Dercon, S., Geddes, A. \& Thomas, D. (2011). The effect of environmental change on human migration. Global Environmental Change, 21 (1), 3-11.

Brigt, D., Larsen, I. B. \& Skorstad, B. (2017) The Will to Drill - Mining in Arctic Communities. Springer Polar Sciences, Springer.

Burn, S., Magdanz, J., Stotts, R., Berman, M. \& Kofinas, G. (2016) Are mixed economies persistent or transitional? Evidence using social networks from Arctic Alaska. American Anthropologist, $118,121-129$.

Capello, R. (2009) Indivisibilities, Synergy and Proximity: The Need for an Integrated Approach to Agglomeration Economies. Tijdschrift voor Economische en Sociale Geographie (TESG), 100 (2), 145-159.

Caravelis, M. \& Russell, I. (2001). From Mining Community to Seasonal Visitor Destination: The Transformation of Sotiras, Thasos, Greece. European Planning Studies, 9 (2), 187-199.

Gill, A. \& Sevigny, D. (2015) Sustainable Northern Development. The Case for an Arctic Development Bank.

Gomberg, E. S. (2003). Treatment for alcohol-related problems: special populations: research opportunities. Recent Development in Alcoholism, 16, 313-333.

Graves, K. (2005). Resilience and adaptation among Alaska Native men. M.A. Thesis, Department of Psychology. Anchorage, AK: University of Alaska.

Ignatyeva, I. A. (2013) State ecological expertise and EIA in the Arctic zone of the Russian Federation: legal regulation, characteristics and problems. Russian Law: theory and practice, 1, 45-51.

Jorgensen, J. G. (1990). Oil age Eskimos. Berkeley: University of California Press.

Hamilton, L. C., Saito, K., Loring, P. A., Lammers, R. B. \& Huntington H. P. (2016). Climigration? Population and climate change in Arctic Alaska. Popul Environ, 38(2), 115-133.

Hausmann, R. \& Rodrik, D. (2002). Economic development as self-discovery. NBER Working Paper Series. № 8952 (May). 44 p.

Heleniak, T. \& Bogoyavlensky, D. (2015). Arctic populations and migration. Arctic human development report: Regional processes and global linkages. Copenhagen: Nordisk Ministerråd, pp. 53-104.

Howe, E. L., Huskey, L. \& Berman, M. D. (2014). Migration in Arctic Alaska: Empirical Evidence of the Stepping Stones Hypothesis. Migration Studies, 2 (1), 97-123.

Kondrashev, A., Nikitenko, M., Trofimova, S., Trofimova, I. \& Gotsko, L. (2016). The Arctic states' strategies and the northern regions' food security. Economic Annals XXI, 162 (11-12), 32-37. 
Koptseva, N.P. (2013). The results of theoretical and experimental research of the modern problems of the indigenous small-numbered peoples of the North, Siberia and the Far East in Siberian Federal University. Journal of Siberian Federal University. Series: Humanities, 6 (5), 762-772.

Kozlov, A. I. \& Zdor, E. V. (2003). Whaling products as an element of indigenous diet in Chukotka. Anthropol. East Europe Rev., 1, 127-137.

Kozlova, E. V. \& Ushakov, D. S. (2016) Current approaches to national migration policy development: principal conditions and factors of efficiency. Actual Problems of Economics, 7, 316-325.

Michał, Ł., Graczyk, P., Stępień, A. \& Smieszek, M. (2015). Cele i oczekiwania Arctic polskiej polityki. Warszawa, PL: Ministry of Foreign Affairs, Department of European Policy.

Morgan, K. (2004). The exaggerated death of geography: learning, proximity and territorial innovation systems. Journal of Economic Geography, 4, 3-21.

Niels, E., Larsen, J. N. \& Nilsson, A. (2004). Arctic human development report. Akureyri, Iceland: Stefansson Arctic Institute.

On the development of the Arctic zone of the Russian Federation: Draft of the Federal law of the Russian Federation. URL: http://docs.cntd.ru/document/555622319.

Otto, A. \& Fornahl, D. (2007). Growth determinants of young businesses in Germany - Effects of regional concentration and diversification. Papers of the 47th ERSA Congress in Cergy.

Overpeck, J., Sturm, M. \& Francis, J. A. (2005). Arctic system on trajectory to new state. EOS, 86 (24), 309-316.

Peshkova, M.K. \& Savon, D.Y. (2016). Mechanism of the government and private business partnership in ecological-and-economic appraisal of mining waste. Gornyi Zhurnal, 10, 37-41.

Pilyasov, A.N. (2017) Siberia: in search of new model of development. Journal of Siberian Federal University. Series: Humanities, 10 (11), 1754-1778.

Rodrik, D. (2008). Industrial policy: don't ask why, ask how. Middle East Development Journal, 8, 129.

Rodrik, D. (2013) Green Industrial policy. Princeton: Princeton University Press.

Sabathil, G. (2010) A European vision for addressing global security threats. European View, 9 (1), 65-69.

Sachs, J. \& Warner, A. (2001). The curse of natural resources. European Economic Review, 45, 128132.

Samarina, V.P., Skufina, T.P. \& Baranov, S.V. (2016). The place of Russia among the largest world exporters. Actual Problems of Economics, 1 (175), 33-43.

Samarina, V. P., Skufina, T. P., Samarin, A. V. \& Baranov, S. V. (2016). Some problems of antirecessionary public management in Russia at Present. Management of Systems of SocioEconomic and Legal Relations in Modern Conditions of Development of Education and Society, $6(6 S)$, 38-44.

Samarina, V., Skufina, T., Samarin, A. \& Ushakov, D. (2018). Alternative Energy Sources: Opportunities, Experience and Prospects of the Russian Regions in the Context of Global Trends. International Journal of Energy Economics and Policy, 8(2), 140-147.

Saxenian, A.-L. (2006). The new Argonauts. Regional advantage in a global economy. Cambridge, Massachusetts and London, England: Harvard University Press. 


\section{MIGRATION AND SOCIAL - ECONOMIC}

Silin, A.N. (2015). Long Distance Commuting in Oil and Gas Production Industry in the Northwestern Siberia: Sociological Analysis of Change. Mediterranean Journal of Social Sciences, 6 (3), 5, 199-206.

Skufina, T., Baranov, S, Samarina, V. \& Shatalova, T. (2015). Production Functions in Identifying the Specifics of Producing Gross Regional Product of Russian Federation Mediterranean Journal of Social Sciences, 6 (5), Supplement 3, 265-270.

Skufina, T. P., Samarina, V. P., Krachunov. H. \& Savon D. Yu. (2015). Problems of Russia's Arctic Development in the Context of Optimization of the Mineral Raw Materials Complex Use. Eurasian Mining, 2 (24), 18-21.

Shepovalnikov, V.N., Onoshko, V.A., Avrusin, S.L., Burtseva, T.E., Solodkova, I.V., Sinelnikova, E.V., Chasnyk, V.G. \& Tomskiy, M.I. (2010). Solar-biosphere interactions and human health in the far North. Yakut Medical Journal, 1, 85-89.

Shephard, R.J. \& Rode, A. (1996). The health consequences of "modernization": Evidence from circumpolar peoples. Cambridge, Cambridge University Press.

Socioeconomic development of the Arctic zone of the Russian Federation: Decree of the Government of the Russian Federation from April 21, 2014, № 366. URL: http://docs.cntd.ru/document/499091750

Spence, J. (2014). Strengthening the Arctic Council: Insights from the architecture behind Canadian participation. Northern Review, 37, 112-118.

Suopajärvi, L., Ejdemo, T., Klyuchnikova, E., Korchak, E., Nygaard, V. \& Poelzer, G.A. (2017). Social impacts of the "clocal" mining business: case studies from Northern Europe. Mineral Economics, 1 (30).

Suopajärvi, L., Poelzer, G.A., Ejdemo, T., Klyuchnikova, E., Korchak, E. \& Nygaard, V. (2016). Social sustainability in northern mining communities: a study of the European North and Northwest Russia. Resources Policy, 47.

Todtling, F. \& Trippl, M. (2004). Like Phoenix from the Ashes? The Renewal of Clusters in Old Industrial Areas. Urban Studies, 41 (5/6), 1175-1195.

Torre, A. \& Wallet, F. (2014). Regional Development and Proximity Relations. Cheltenham, UK and Northampton, MA, USA: Edward Elgar.

Tötzer, T. \& Gigler, U. (2005). Managing urban dynamics in old industrial cities: Lessons learned on revitalising inner-city industrial sites in six European case studies. Amsterdam: 45th Congress of the European Regional Science Association - Land Use and Water Management in a Sustainable Network Society.

Trippl, M. \& Otto A. (2009). How to turn the fate of old industrial areas: a comparison of clusterbased renewal processes in Styria and the Saarland. Environment and Planning, 41, 1217-1233.

Ushakov, D., Elokhova, I. \& Kozonogova, E. (2017). Postindustrialization prospects in the dynamics of socioeconomic transformations: cluster approach. International Journal of Ecological Economics and Statistics, 38 (2), 23-32.

Federal State Statistics Service of the Russian Federation. URL: http://www.gks.ru/wps/wcm/connect/rosstat_main/rosstat/en/main/

Fenna, D., Mix, L., Schaefer, O. \& Gilbert, J.A. (1971). Ethanol metabolism in various racial groups. Canadian Medical Association Journal, 105, 472-475.

Fujita, M. \& Mori, T. (1998). On the dynamics of frontier economies: endogenous growth or the selforganization of a dissipative system? The Annals of Regional Science. February, 32 (1), 39-62. 
Waldram, J.B., Herring, D.A. \& Young, T.K. (1995). Aboriginal health in Canada: Historical, cultural, and epidemiological perspectives. Toronto, University of Toronto Press.

Wood, D.S. (1999). Inuit and non-Inuit alcohol consumption in the Baffin Region. International Journal of Circumpolar Health, 1, 24-29.

Zamaraeva, Ju. S. (2014). What are global transformations experienced by the indigenous peoples of the North? Journal of Siberian Federal University. Series: Humanities, 10 (7), 1705-1718.

Zamyatina, N. Y. (1998). Area Development (frontier) and its image in the American and Russian cultures. Social science and modernity, 5, 75-89.

Paper submitted

Paper accepted for publishing

Paper published online
14 May 2018

26 June 2018

30 September 2018 